\title{
INDONESIAN TAKFIRI MOVEMENT ON ONLINE MEDIA IN UMBERTO ECO'S SEMIOTIC PERSPECTIVE
}

\author{
Aniek Nurhayati \\ Universitas Islam Negeri Sunan Ampel Surabaya, Indonesia \\ E-mail: a.nurhayati@uinsby.ac.id \\ Dwi Astiti Hadiska Putri \\ Universitas Islam Negeri Sunan Ampel Surabaya, Indonesia \\ E-mail: astithadiska@gmail.com \\ Andin Desnafitri \\ Universitas Islam Negeri Sunan Ampel Surabaya, Indonesia \\ E-mail: desnandine@gmail.com
}

\begin{abstract}
In the era of online media, the Takfiri movement uses website and social media to propagate its religious understanding. In Indonesia, they also do the same. Through a semiotic perspective, this paper seeks to question how communication and interpretation are carried out by Takfiri groups in producing signs, and how they express signs in online media. The relevance of Umberto Eco's semiotics is due to its communicational character, and as a contemporary semiotic philosopher, Eco has reminded of how sign production is happening in the era of internet technology. With narrative and semiotic analysis methods, this paper draws data from online media in the form of websites and social media such as Twitter, Instagram and Facebook. The analysis shows that Takfiri content in online media, which creates radical attitudes in some circles of society, has been captured without a meaningful process, so there is no critical thinking process. The propaganda of Takfiri is expressed in the very well-known sentence, al-walà' wa albarà, namely love and loyalty to believers and hate, and hostility to unbelievers, and it is a sign that Takfirism is an ideology whose followers are ready to commit violence in the name of religion.
\end{abstract}

Keywords: Takfiri movement; online media; Umberto Eco's semiotics 


\section{Introduction}

In the industrial era 4.0., online media has a very big role. The mass media, which has been presented through paper for several centuries, is currently read through online media. By using online media, the information presented only requires data quota and information technology (IT). This facility is used by many groups to disseminate various information, both about lifestyle, science, economic development, culture, politics, including ideology and religion. Religious discourse through online media is running excitedly and colorful because anyone can participate in it.

How religiosity is developed in the media, Helland ${ }^{1}$ argues that with the development and expansion of the Internet to the world are accommodated by individuals and groups who wish to "become" religious outside the control of organized religious institutions. In fact, official religious organizations have also flocked to cyberspace, trying to establish their presence, control and authority over the growth and development of religion. In fact, individuals and groups use the internet to develop their religious beliefs and wings on online media, as a new environment for freedom of expression. As a form of computer-mediated communication, the internet has become an ideal medium for communicating religious beliefs and practices in a social context.

This paper will analyze how the online media is used by one of the radical Islamic ideological groups, Takfirism, in spreading their ideological values. Takfirism can be understood as calling infidel to people other than Islam, or Muslim who are not part of their group. The doctrine was developed based on their understanding of religion and the teachings they quoted from religious texts either the Qur'ān, Hadīth or other salaf books that supported their thinking. The label of infidel to "others" is not only a discourse, but in practice they always relate to someone leaving from their religion (Islam) and the threat of its annihilation in the world and its insecurity in the hereafter. ${ }^{2}$

\footnotetext{
1 Christopher Helland, "Online Religion as Lived Religion: Methodological Issue in the Study of Religion Participation on the Internet," Heidelberg Journal of Religions on the Internet, Vol. 1, No. 1 (2005), 1-2.

${ }^{2}$ Haidar Bagir, Islam Tuhan Islam Manusia: Agama dan Spiritualitas di Zaman Kacau (Bandung: Mizan, 2019), 52.
} 
The Takfiri ideologist followers are labeled as radical Islamic groups because they have hardline Islamic thoughts and demand to purify tawhid (monotheism). The intolerant attitude and strict towards existing of the rules make them tend to live in an exclusive community. According to Nadirsyah Hosen, several groups that are categorized as radical are: 1) The Takfiri group which always considers other as infidel, including their own Muslim brothers; 2) A group of jihadists who do not hesitate to kill and persist their hearts to always go to war. They kill other people on the basis of jihad, even though the Hadiths are clear about those who can be killed and who cannot; 3) The movement groups that have vision and mission to form an Islamic State or restore the ideology of the caliphate. ${ }^{3}$

Takfirism argues that all the thoughts that are not in accordance with the Qur'ān and Hadìth will be labeled as bid'ah (religious innovation) and even the perpetrators labeled them as infidel or even musbrik (polytheist). This is a hard ideology that easily kicks a person and makes his ideology the most true ideology is transmitted through the media both online and offline. They are required to be able to keep up with the times so that they recruit more people who accept their ideology, and online media is an easy choice for this group to do.

The studies show how radical Islamic ideology and antiradicalism, to Islamophobia have been spread in online media and have become a concern among academics. The research of Hidayatullah ${ }^{4}$ shows how online media has been used as a medium for hate speech against other groups (in Islam) and other religions. Ghifari $^{5}$ also shows that radical groups have spread their understanding of Islam from books to the virtual world.

\footnotetext{
3 Zulfadli, "Pendidikan Politik dala Menangkal Pemahaman Radikalisme Agama bagi Pemuda Muhammadiyah di Kecamatan Pariaman Utara, Kota Pariaman," Warta Pengabdian Andalas, Vol. 26, No. 1 (2019), 24.

4 Moch Syarif Hidayatullah, "The Sectarian Ideology of the Islamic Online Media in Indonesia," INS ANIY AT: Journal of Islam and Humanities, Vol. 1, No. 2 (2017).

5 Imam Fauzi Ghifari, "Radikalisme di Internet," Religious: Jurnal Agama dan Lintas Budaya,Vol. 1, No. 2 (2017).
} 
In line with this, Sulfikar ${ }^{6}$ saw how radical movements change the printed to virtual media, and because they are accessed all over the world, the ideology then easily spreads. Due to the uncontrolled speed of internet media, this ideology spreads very quickly. In the last two decades, radical Islamic movements in Indonesia have continued to increase. Even though prevention and countermeasures are being carried out by the government, these extremist groups continue to emerge. They use the internet as a catalyst for violence and an effective propaganda tool to gain support from sympathizers. Meanwhile, Sutkute ${ }^{7}$ who conducted studies in Kashmir and Lebanon, showed that online media not only socialize and inform, but also mobilize people to not only follow values, but also take certain actions. Therefore, Ghifari ${ }^{8}$ pointed out that radical groups have spread their understanding of Islam from books to the virtual world

This paper mainly seeks to see how a radical movement, like Takfiri movement in Indonesia, operates on online media based on Umberto Eco's semiotic analysis. Online media as a culture has become a communication space through the expressions which are shown by adherents of this ideology. This is relevant to the semiotics that was initiated by Eco, who tries to see semiotics from the cultural aspect. Through cultural units in culture, Eco calls his semiotics as communicational semiotics. In the writings of Rahman, ${ }^{9}$ Eco's semiotics is much opposed by semiotics experts. However, this paper relies on Eco's school because it sees the relevance of Eco's opinion, that in the virtual media era, there are many sign-reading processes that no longer use human consciousness, but IT. It is often encountered here, how commonsense has defeated trending issues in media.

Regarding this background, this paper seeks to answer how the Takfiri movement communicates with the public through online media, and how the expression of the Takfiri group in the media is

6 Achmad Sulfikar, "Swa-radikalisasi Melalui Media online di Indonesia," Jurnalisa, Vol. 4, No. 1 (May 2018).

7 Rita Sutkute, "Media, Stereotypes and Muslim Representation: World After Jyllands-Posten Muhammad Cartoons Controversy," EUREKA: Social Humanities, No. 6 (2019), 66.

${ }^{8}$ Ghifari, "Radikalisme di Internet."

9 Abdul Rahman dan Tommy F. Awuy, "Semiotika Filosofis: Perspektif Umberto Eco" (Undergraduate Thesis--Universitas Indonesia, 2013), 34. 
represented in their content. Based on the problems, the data of this study were taken from online media that initiated Takfiri ideas, and the data analysis used narrative and semiotic analysis. Narrative analysis ${ }^{10}$ is used in connection with the data taken in the form of documents or texts in online media. So far, the texts in online media in the context of the Takfiri movement have been narrated by the narrator's point of view, which then takes various forms and is told with various settings.

Narrative analysis to some extent can be more extreme, that is, macrotextual analysis, where it can observe the verbalization process of a community or group through words, which can also be seen in the narratives carried out by Takfiri groups on online media. The process of verbalization is a process of representation as well, and in this process, there are elements to dramatize and construct social relations. With this method, it can be seen how the process of representing the Takfiri movement, seeing how the dramatization is happening, so that it can be interpreted.

The semiotic analysis is used to see that all the forms of human communication are actually signs. The basic material of a sign is expression and content. ${ }^{11}$ This is how semiotics tries to see how the meaning of expression and content of the texts are publicspirited. Therefore, the semiotic analysis method will provide the meaning related to how the expression of Takfiri groups and radical contents that fill their pages in online media.

\section{The Takfiri Movement: Birth, Development, and Phenomenon}

Terminologically, "Takfiri" (takfiri) comes from the words kafara-yakfuru-kufränan, which means to cover as in the use of covering the blessings called kufr ni'mah. There are two types of infidel in the prophetic era, those are non-semitic infidel or what is commonly known as Makkah infidel and semitic infidel, those who have heavenly (samämi) Holy Books and worship God. These Makkah infidel are what is called in the Qur'ān "yā ayyuba alkäfirün." They worship idols, consecrate of God, do not believe in

\footnotetext{
${ }^{10}$ Peter K. Manning and Betsy Cullum Swan, "Analisis Naratif, Analisis Konten dan Analisis Semiotik," in Norman K. Denzin, Handbook of Qualitative Research (Yogyakarta: Pustaka Pelajar, 2009), 616-617.

${ }^{11}$ Ibid., 618.
} 
Heaven, but different from Semitic infidel who still believe in God and believe in Heaven. ${ }^{12}$

Takfirism began with the Khawarij phenomenon which formulated a doctrine of infidelity on the basis of the Qur'àn, and they considered Muslims who were not from their group to be considered as infidel and their blood is lawful. The beginning of infidel was carried out by members of the Khawarij group, those were al-Barak b. 'Abd Allāh, 'Amr b. Bakr, and 'Abd Raḥmān b. Muljam who wanted to implement the ideology they considered correct, because they were dissatisfied with their leaders at that time. The leader they called infidel was 'Alī b. Abī Ṭâlib because the Caliph 'Ali agreed to tolerate the tahkim (arbitration) between the Caliph and his enemy, Mu'āwiyah b. Abī Sufyān through the person he appointed, 'Amr b. al-'Āṣ. They consider Mu'āwiyah to be a real enemy (bughat) and must be fought because this is the law of Allah that must be applied. Because they did not obey Allah's law, they considered the Caliph 'Ali to be an infidel. As a followup, they sent people to kill Mu'āwiyah and Ibn al-'Āṣ. They failed to kill both of them, but managed to kill the Caliph 'Alī while praying at the mosque. ${ }^{13}$ This was also followed by the existence of false Hadiths to support one group or to insult another group so that the holy verses were used as political tools at that time. ${ }^{14}$

The ideological notion of Takfiri states that a person becomes an apostate or infidel in actions or ideas that voice infidel in Islam. The infidel movement calls someone who is not from their group as infidel and must be killed. ${ }^{15}$ Therefore they have an important role to play in perverting Islam and producing individuals who are willing to commit murder to both Muslims and non-Muslims. ${ }^{16}$

The infidel status has been assigned to someone who does not believe in the existence of Allah as God Almighty and also to someone who associates Allah such as idol worshipers, people of the holy book (Jews, Christians) and the Infidel Quraish. The

\footnotetext{
12 https://youtube/hlPX5RXtXcY, accessed on March 4, 2021.

${ }^{13}$ Bagir, Islam Tuban Islam Manusia, 47-49.

${ }^{14}$ Nadirsyah Hosen, Saring sebelum Sharing (Yogyakarta, Bentang: 2019), 300.

15 Steven W. Newell, Global Takfiri Radicalization: A Center of Gravity Deconstruction (Newport: Naval War College, 2010), 2.

${ }^{16}$ Ibid., 3-4.
} 
Qur'ān has also warned Muslims to avoid disbelievers and täghüt. ${ }^{17}$ The term infidel then metamorphoses into a religious term which has a specific meaning in punishing the religious way of a certain person or group. The word infidel comes from the word kufr, which means renouncing faith ${ }^{18}$ and it is anonymous with the word taslim which means surrender to Islam. ${ }^{19}$

In the past, Muslim theologians (mutakallimün) discussed tawhid which determines the substance of Allah and negates Him, in its development these mutakallimin were divided into a number of theological schools. From each of these schools, they made a theological formula by discussing and understanding the Qur'ān and Hadith, so that they could produce many works which were later referred to the knowledge of kalam. In its development, it turns out that the problems arise when one theological school views the truth as absolute and the other group is wrong. This conflict affected to social and political life in society. There are even some mutakallimins, who claimed that those who believe by taqlid their faith, are accused of being invalid. Even though their taqlid is valid, they were still considered as disbelievers by this group. This extreme attitude was then responded by al-Ghazālī, that they were overreacting by calling infidel to laying Muslims and seeing anyone who did not understand 'aqidah with the argument they described was an infidel. So, they have narrowed down God's grace and made heaven especially for them theologians. This attitude is then followed by some Muslims at this time, calling infidel to someone with the criteria of a flag bearing the tauhid word, the choice of political parties, or even the choice in the governor and presidential elections. ${ }^{20}$

The radical ideology wants Muslims to fully adhere to the Qur'ān and Hadīth in carrying out state regulations, thus rising to the concept of the Islamic caliphate, followed by the Islamic revolution and jibäd. These people consider that the concept they are promoting is the most correct and tend to disbelieve and label

\footnotetext{
17 M. Hafidh Widodo, "Ideologi Takfiri Muhammad Al-Maqdisi," Living Islam: Journal of Islamic Discourses, Vol. I, No. 2 (November 2018), 380.

${ }^{18}$ Ibn Mandhūr, Lisān al-'Arab (Kairo: Dār Ma'ārif, 1119), 3897.

${ }^{19}$ Widodo, "Ideologi Takfiri," 380.

${ }^{20}$ https://islam.nu.or.id/post/read/98243/mengafirkan-sesama-muslim-takfiri dulu-dan-sekarang, accessed on March 5, 2021.
} 
shirk to those who have different ideologies. This is what makes the Takfiri movement also allow killing and committing violence against those who are considered infidels. ${ }^{21}$ For example, the laws and regulations made which made by the parliament and senate are inconsistent law with the Qur'ān and Sunnah. These products are thogut products that have been believed apart from Allah. So that they are not only hostile to the legislators, but also must be followed by labeling and punishing the infidels against these people. $^{22}$

In fact, the previous scholars applied the principle of prudence before dropping the labelling infidels. As explained in the book of al-Shifä' bi Ta'rif Huqūq al-Mustafä with the sharh (explanation) of Mulla 'Alī al-Qàrī al-Harawī in Hanafì school, explained that the evidence contained in Muslim brothers that leads to disbelief should be reconsidered, if something goes wrong one proof in him that still holds on to Islam. Labeling infidels leads to consequences that are not light, such as being killed if he does not repent, loss of inheritance rights, fasakh of their marriage, and thaving the biggest consequences in the afterlife world. ${ }^{23}$

One of the figures who campaigned strongly for the concept of takfir was Muhammad al-Maqdisī. He is one of the important figures of the Salafi-Jihadi sect originating from Palestine, who later became a major leader of the Al-Qaeda jihad movement in Iraq and Syria. Now the Salafi-Jihadi sect of al-Maqdisi has changed Islamic State of Iraq and Syria (ISIS) which is now led by Abū Bakr al-Baghdādī. In fact, because of his influences, he is also known as the Godfather of the contemporary Takfiri ideology.

Al-Maqdisîs thought was influenced by the Palestinian-Israeli war. He was a student of the Muslim Brotherhood haläqah (circle) of Ḥasan Ayyūb and Gharīb Tawba. Hassan Ayyūb himself is a da'wah figure who in his preaching often conducts studies that tend to oppose and find fault with Muslim rulers in the political side of Islam in the Arab world. Al-Maqdisī himself was an admirer of clerical figures who were critical of criticizing government rulers. So that the critical thinking and ideology of al-Maqdisi was inspired by these criticisms, even al-Maqdisi considers that the

\footnotetext{
${ }^{21}$ Widodo, "Ideologi Takfiri," 382.

22 Ibid., 392.

${ }^{23}$ Hosen, Saring sebelum Sharing, 302.
} 
Islamic monotheism followed by the government is tawhid which is illegitimate and is even considered infidels because violating the tawhìd rules in the Qur'ān and Hadīth. ${ }^{24}$

Beside inspiring by Hassan Ayyūb, al-Maqdis̄̄ was also inspired by the salafism of Muhammad Surūr Zayn al-'Ābidīn..$^{25}$ During his searching for inspirational figure, then he met Sayyid Quṭ. After his introduction to Sayyid Qutb's thoughts, al-Maqdisī became knowing about jihad education to eradicate rulers who were considered zălim to Muslims. Apart from that, al-Maqdisī learned more about jihad from several salafi scholars, namely Muhammad Nāṣir al-Dīn al-Albānī and 'Abd al-'Azīz b. Bāz. In addition, alMaqdisis thoughts were further honed while studying at the Islamic University of Medina and meeting many students and teachers, as well as several shaykhs from Salafi community.

Al-Maqdisī argues that there are reasons that must be considered in infidels because the consequences of takfir are very heavy, such as the law of guardianship, law of marriage, law of inheritance distribution, law of funeral prayers, and regarding the halalness of blood and property. He mentioned that there are seven people who can be called infidels, except those who believe that knowledge and faith must be in accordance with the Qur'ān and Hadith, do not deny Allah's attributes, believe that they can see Allah in the hereafter, believe that Allah is above 'arsh, believes in the Qur'ān as the word of Allah, believes that Allah spoke with the Prophet Moses and the latter believes in God's law and does not replace it with human law. ${ }^{26}$

From the concept of Muh $\}$ ammad Al-Maqdisis's Takfiri, he reiterated that Muslims should not be friendly towards infidels people, discard their love and show hatred towards them. Hating and denying disbelief must be raised firmly and harshly because humans are God's soldiers on earth who must minimize from plunging into infidels.

There are at least three works of Salafi's great figures who inspired al-Maqdisī's radical ideology, namely Ibn Taymīyah and

\footnotetext{
24 Widodo, "Ideologi Takfiri," 384-389.

${ }^{25}$ Gilles Kepel, The War for Muslim Minds: Islam and the West, translated by Pascale Ghazaleh (London: Belknap-Harvard University Press, 2004), 176.

${ }^{26}$ Widodo, "Ideologi Takfiri," 393.
} 
his students, Ibn al-Qayyim al-Jauzīyah and Muhammad b. Wahhāb. Al-Maqdisī has been accustomed to living in a salafi and wahabi environment, so it cannot be denied that his ideology has become radical and Takfiri. They easily call people as infidels, even looking for loopholes to criticize the Muslim governments and call them as the leaders who are wrong and infidel. Al-Maqdisī has also known Salafi and Wahabi from the book al-Durar al-Saniyah fi alAjwibät al-Najdiyah, which contains various fatwas of Wahabi scholars which consist of several volumes of writings.

Furthermore, there are differences in the concept of infidel according to salaf and khalaf, both of those are provisions of the sharî'ah contained in the Qur'ān and Sunnah. Like faith which has different levels, infidelity also has the levels from the heaviest to the lightest. The lightest level is immoral acts that make the perpetrator sinful and will be punished, while the toughest is to remove Muslim from their religion, which is known as murtad. Takfir according to salaf and khalaf are both sourced from the Qur'ān, Sunnah, ijmā', and itibār of the companions of the Prophet. Even though they originate from the same sources, they have differences in understanding of infidels can still be seen, and this is more due to the rapidly developing and adapting framework of the mind at that time. ${ }^{27}$

The Takfiri is considered closer to the Wahabi, which demands their followers return to the purification of tawhid as exemplified by the Prophet Muhammad and as stated in the al-Qur'ān. Wahabi created an Islamic reform that seemed very radical, intolerant and aggressive, ${ }^{28}$ where his followers consider those who are not Wahabi followers, even though Muslims, they are doing bid'ah. One of the Wahabi's ways to attract new followers is by heralding da'wah platform to combat shirk, and they provide a forum for questions and answers of Islamic studies that are spreading throughout the mosque or even now penetrating online media. When people ask about fiqh and sharīah, they will easily label

27 Azhar, "Analisis Komparatif Konsep Takfir antara Salaf dan Khalaf," AlLubb, Vol. 2, No. 1 (2017), 120-138.

28 Arina Rahmatika, "Citra Wahabi di Media Massa," Mediakita, Vol. 2, No. 2 (July 2018), 99-100. 
anything that is not in line with their ideological understanding as heretic. ${ }^{29}$

The Takfiri movement seems to be contradicting the Sunni and Shia schools because the two schools are deemed incompatible with the purification of Islam according to the alQur'ān and Hadīth. They are more likely to promote extreme thinking in religion. This extremimism was not justified by Rasulullah. This can be seen when 'Abd Allāh b. 'Umar was too busy in worship and neglecting his family, Rasulullah admonished him to balance the world and the hereafter. The obligation that must be carried out in the world is not only to worship, but also to be responsible for their children and their wives. ${ }^{30}$

Regarding the phenomenon of the Takfiri which in many aspects has "shaken" many circles, the study of this movement also continues to develop. Widodo ${ }^{31}$ wrote about al-Maqdisis's Takfiri ideology to understand the relationship between religion and state in the perspective of maqasid al-shari $a b$. This paper explains the dangers of Takfiri ideology if it continues to be applied in the life of a Muslim. This distorted understanding in the concept of Takfiri has resulted in many groups or movements that are legitimate by the existence of the fatwas that they issued. The Fatwas later become the hold of ordinary people and can lead to conflict between Muslims and non-Muslims. This fanatical attitude has led to the behavior of tabdi', takfiri and tashrik.

Furthermore, research conducted by Mohamed Badar, Masaki Nagata, and Tiphanie Tueni analyzed the chaos that caused by the deviant concept of Takfiri as a legal action based on the Qur'ān and Sunnah. Like the ideology of the ISIS, which justifies any means to show their disagreement with all other ideologies than those they hold to the extreme, such as isolating other Muslims and declaring that they have left Islam, so that they are allowed to be killed. ${ }^{32}$

\footnotetext{
${ }^{29}$ Shaykh Idahram, Ulama Sejagad Menggugat Salafi Wahabi (Yogyakarta: Pustaka Pesantren, 2011), 67-93.

${ }^{30}$ Amanullah Halim, Buku Putih Kaum Jihadis: Menangkal Ekstremisme Agama dan Fenomena Pengafiran (Tangerang: Lentera Hati, 2015), 7-8.

31 Widodo, "Ideologi Takfiri," 405.

32 Mohamed Badar et al., "The Radical Application of the Islamist Concept of Takfir," Arab Law Quarterly, Vol. 31 (2017), 132-160.
} 
The relation between Takfiri and Sunnah and Shia groups, Mulyana explained that the conflicts arising between these two relationships are the issues related to values, claims, identity on this religious issue which can actually be solution resolved. ${ }^{33}$ However, this is prevented by groups acting on behalf of Muslims but who are easy to convict, slander, and even disbelieve other Muslim brothers from different schools of thought due to differences in views and ideas, which are commonly called Takfiri groups. Even though it is possible to build dialogue for peace, there are still those who claim to represent the Sunni voice who do not want realizing the peace. They have provocative character, and didn't even hesitate to shed the blood to different group from them. The ideological violence they adheres has caused a lot of chaos in Indonesia. How to spread threats and terror against Shia groups is not a new matter, but it has started a long time ago.

As for Hassan, ${ }^{34}$ he saw the relationship between Takfiri and ISIS by discussing the dangers of Takfiri ideology which is the ideology of the terrorist group, The Islamic State or ISIS, which calls for the concept of jibäd and hijrah as well as the rise of the caliphate. They also declare punishments and sanctions against offenders and those who oppose their ideology, the implementation of which deviates from Sunni Islam.

The extremism generated by Takfiri was written by Rabbani Rao, ${ }^{35}$ which discusses the ideology of Takfiri that depicts Islam as an extreme religion so that the effect of Takfirism itself is catastrophic, especially in Pakistan. In terms of physical appearance, Takfiri considers infidels to men who do not have beards and women who do not cover their faces and palms. Takfiri has become a chronic disease with aspects of violence and warfare in the concept of jihad. How then war and violence are chosen for

\footnotetext{
33 Rijal Assidiq Mulyana, "Tanggapan Atas Tulisan Buya Syafi'i Tinggalkan Takfiri Bukan Syiah Bukan Sunni."

34 Muhammad Haniff Hassan, "The Danger of Takfir (Excommunication): Exposing IS' Takfiri Ideology," Counter Terrorist Trends and Analyses, Vol. 9, No. 4 (April 2017).

35 Ammara Rabbani Rao, "Takfiri a Messianic Ideology: Counter Measures for Radical Insurgents in Waziristan," Tigah: A Journal of Peace and Development, Vol. 4 (2014).
} 
jihad, written by Celso ${ }^{36}$ which describes jihadists who use the extreme power of violent Takfiri to fight the enemy of Islam.

Furthermore, the jihad stage of the Indonesian radical Salafi movement, was written by Din Wahid ${ }^{37}$ which explained about the religious doctrines adhered by Salafi Schools such as al-walä' wa albarā', bizbiyah, and bäkimiyah. In the third concept, namely häkimiyah, Salafi groups develop Takfiri ideology, and they divide the rulers into käjir i'tiqädi and káfir 'amalì. The first one is considered to have left Islam, while the second is still under the auspices of Islam even though he has committed a sin.

From various studies that have been conducted by several academics, many discuss the concept of Takfiri ideology which is currently being developed in many parts of the world. The ideology of Takfiri itself has been widely applied in several Islamic groups. However, the movements carried out by these groups are no longer only in the real world, but have penetrated the virtual world through the internet, social media, religious sites which are spread through videos, messages, uploads and so on.

Several studies have shown that online media has been used in propagating Islamic radicalism. Sabiruddin's writing ${ }^{38}$ analyzed about hoax news from radical groups that have spread on social media. This concern surfaced when the spread of hoaxes led to hate speech in the name of religion. Then, radicalism is legitimized in a variety of actions, ranging from infidel people who disagree with them to killing their enemies. This radicalism is characterized by; first, wanting to make changes quickly using violence and in the name of religion; second, Takfiri or excommunicating other people; third, supporting, spreading, and inviting others to join ISIS. At this time, ISIS has become the most feared Takfiri organization. Al-Ghazzi's writing ${ }^{39}$ also explained that ISIS uses

\footnotetext{
36 Anthony N. Celso, "Jihadist Organizational Failure and Regeneration: The Transcendental Role of Takfiri Violence" (Paper prepared for presentation at The Political Studies Association Meeting, Manchester, England, April 14-16, 2014.

${ }^{37}$ Din Wahid, "Pentas ]ihad Gerakan Salafi Radikal Indonesia," Studia Islamika, Vol. 14, No. 2 (2007).

38 Sabiruddin Juli, "Saring sebelum Sharing: Mengenal Berita Hoax, Radikalisme di Media Sosial", Al Munir: Jurnal Komunikasi dan Penyiaran Islam, Vol. 10, No. 1 (2019).

39 Omar Al-Ghazzi, "Modernity as a FalseDeity: Takfiri Anachronism in the Islamic State Group's Media Strategy," Javnost: The Public (2018)
} 
media technology as an important strategy to spread their ideology of Takfirism.

The online media is also used for the recruitment process of this Takfiri group. Djelantik et al. ${ }^{40}$ explained about how to recruit people through social media such as Facebook, Twitter, Youtube and websites by ISIS in Indonesia for the purpose of jihäd in Iraq and Syria. They also carry out communication techniques between one group and another using Islamic-based social media which are classified as radical such as Al-Azzam, Al-Mustaqabal, and Arrachman.com. Changes and developments in terrorism in Indonesia follow the developments of information and communication technology.

The foregoing needs further attention that Indonesia is a country with high social media consumption. The research of Indah saw how this consumption is used by ISIS members to get new jihadists by recruiting. ${ }^{41}$ ISIS uses social media as a means of spreading propaganda and threating as a result of their acts of terrorism. The large number of ISIS followers in Indonesia are the masters of ISIS in using propaganda through various mass media like social media, online media or print media to influence the Indonesian people to contribute to the war in Syria and to practice war by bringing up of terrorist actions in Indonesia.

Researches on the Indonesian Takfiri movement in online media are mostly traced through framing analysis, communication techniques, studies of media and politics, political violence, as well as religious and political studies. This paper seeks to answer a deeper curiosity about how online media is used as a communication medium that creates meaningful signs, and how it is expressed in content on the web and social media.

\section{Takfiri, Communication and Interpretation on Online Media}

Online media as a very influential media in the current era of information technology, as discussed above, has been very wellutilized by Takfiri groups. Umberto Eco's semiotic perspective

\footnotetext{
40 Sukawarsini Djelantik et al., Komunikasi Melalui Media Sosial oleh The Islamic State (IS) di Indonesia (Bandung: LP2M Universitas Parahyangan, 2015), 127-142.

${ }^{41}$ Nuria Indah, "Pengaruh Media Sosial terhadap Penyebaran Paham Terorisme Islamic State of Iraq and Syiria (ISIS) di Indonesia" (Undergraduate Thesis-Universitas Pasundan, 2019).
} 
becomes relevant because of its communicational characteristics. It is not surprising that the semiotics are referred to as communication semiotics. Semiotics according to $\mathrm{Eco}^{42}$ examines that all cultural processes represent communication process. The foundation of the semiosis process takes place in the significance system. Eco stated the importance of distinguishing the semiotics of significance and the semiotics of communication, but he reminded that this difference does not put the two approaches against each other.

Every cultural output can become a semantic unit, because of its interdisciplinary nature, and only a precise interpretation can understand such a unit. Regardless of what has to do with interpretation, the concept used mainly from the 1960s to the 1980 s when the text leaves the author's hands, it finds itself endless in a queue of interpretations that may or may not be limited by context. For example, according to deconstruction theory, it is impossible to interpret a text with certainty, and various interpretations are, almost always, valid. This is because each sign can be quoted in any way and may also be separated from the original context to create a new context, unlimited, and free from the criteria of all interpretations. Text is part of a chain of interpretation that must continue without the presence of the author or considering the context. The interpretation of the text is also described as a tool to produce unlimited signifying meanings. ${ }^{43}$

Therefore, the sign obtained from the information released by the author, in the context of Eco semiotics which is influenced by postmodernism; the interpretation is freely carried out by the reader, regardless of the author. An example that can be presented here is the news that has shocked the world in the midst of a pandemic, namely the shooting of a French teacher by "jihadists" because he gave an example of freedom of expression by making cartoons that mocked the Prophet Muhammad. The news received mixed responses, there were several groups that condemned the shooting in the name of freedom of expression and humanity.

42 Umberto Eco, Teori Semiotika: Signifikasi Komunikasi, Teori Kode, serta Teori Produk-Tanda, translated by Inyiak Ridwan Muzir (Kreasi Wacana: Bantul, 2016), 8-9.

43 Martin Solik, "Semiotic Approach to Analysis of Adverting," Journal of Science and Theology, Vol. 10, No. 1 (October 2014), 208. 
Some regretted the behavior of the teacher, but criticized the shooting. The latter group is a representative of jihadists or Salafis by supporting the shooting.

This also reaches in Indonesia where the three groups are present on social media together. The last group, for example, posted by Maheer via twitter, saying that beheading the insulting the Prophet Muhammad was an achievement. ${ }^{44}$ The achievement is given by Takfiri for the case of the teacher's shooting, which can be interpreted as a spirit of hostility and likens it to an arena of war, where the enemy can be shot dead.

This is the power of online media, including social media can sedate many people by producing the signs. Before the explosion of today's online media, Sarigul ${ }^{45}$ mentioned that Eco had warned in his writing "Number Zero," about the dangers of news coverage in the printed newspaper. Eco sees that in the newspapers, the readers feel that the public is being treated not based on "reality," but the media have designed various messages, stories and ideas that must be comfortable and close to the tendencies in the minds of the people. The content that is released to the media places all human beings into a passive state. Information and news are far from an important purpose. The purpose of preaching is neither to tell the truth nor to direct the reader to the truth. It is a postmodern approach and emphasizes market demands and needs. Eco reveals the tricks of the newspapers when they cannot find any news to publish, so they cover up some events, fake news they create, and issue stories in the framework of schaden freude principle (happiness from other people's sadness), preform files about the potential enemies that they might encounter one day and use it as a threat, by defaming the target of person or institution. They "value" unimportant stories through stylistic methods of placing them under headings and the tactics they use to drag the reader in a certain direction from their own point of view.

What Eco stated about print media which contains a lot of fake news is not surprising. In Indonesia, at a time when the

\footnotetext{
44 Twitter, @islamidotco, posted on November 13, 2020.

45 Fatma Altınbaş Sarıül, "The Impact of Print Media on Popular Culture: Umberto Eco's Number Zero," Istanbul Kemerburgaz University Journal of Social Sciences, Vol. 1, No. 1 (2016), 80-81.
} 
printed media era was still busy, educated circles only trusted a few print media that could provide information that was considered correct. Many print media emphasized gossip, blasphemy, the phenomenon of violence, or display the lifestyles of a few rich people or celebrities who cannot be reached by the general public. Political news cannot be trusted either because the media is partisan from certain political parties. In the era of the printed media, Takfiri propaganda has not yet found such a powerful moment, due to the limitations of the print media which require a longer chain in disseminating information. In the current era, where the printed newspaper media have experienced "suspended animation," false information, propaganda and others are easier to do because of the wide, free and cheap online media coverage.

As a contemporary semiotics figure, Eco, who died in $2016^{46}$ have seen how the power of the internet as a tool for information media. Eco calls the website the "Mother of All Lists" with dangerous implications for human culture. His work shows that the algorithmic processing of big data on the medium of the internet has threatened cultural development, by limiting human involvement in significance and communication. For Eco, meaning is human meaning through interpretive insight, different from communication, which is centered on the transfer of information that is manifested from sender to receiver. While the field of communication often refers to communication that includes information transfer and interpretation, Eco differentiates these tasks with meaning, not communication. Meaning will encourage interpretive responses. Eco emphasized the importance of meaning in securing interpretive responses and cultural meanings, as well as the simultaneous value of communication as work that activates and enriches meaning between and among interpreters. He further warned that the algorithmic governance of the internet acts as a potential barrier to human meaning by limiting the continuity of communication and meaning. ${ }^{47}$

The rise of Takfiri contents on online media, which has led to radical attitudes in some circles of society, shows that the sign messages produced by these groups have been captured and

\footnotetext{
${ }^{46}$ Beritanica.com/biography/Umberto-Eco, accessed on March 9, 2021.

47 Susan Mancino, Understanding Lists: Umberto Eco's Rhetoric of Communication and Signifcation (Ph.D. Dissertation--Duguesne University, 2018), 13.
} 
without a meaningful process, so that there is no critical thinking process. This raises the question of how online media has produced signs. In this context, Eco pointed out the importance of semiotics and emphasized his contribution to interpretative semiotics. He argues for theoretical engagement with the understanding of the interpretive involvement of the reader's text. Eco identifies the coordinate centers available in the media and looks for performative responses to view markers and communications in the internet era. Both articulate the relevance of the Eco project as the theoretical foundation behind the questions that fuel this investigation: what is the role of human markers and communication in the internet age and how humans can protect and promote human meaning amidst this trending technology.

Regarding the current era of online media, Eco emphasized to always be aware of the political situation, and according to him this is one of the tasks of critical thinking. Eco sees the role of new media in determining present day considerations, and through social media and other new media channels, media has involved mass psychology. In these media, social networks have allowed thousands of people to communicate simultaneously and lost "critical control." 48

It cannot be denied that politics is a consumption that is often used by radical Islamic groups (Takfiri) as a justification for their ideology. The current condition, for example, is that they are in a binary opposition position with the government so that whatever government policies can be used to propagate their ideology. For example, hoax news about Maheer's death. According to the news circulating from Facebook posted that Maheer died because he was forced to get a vaccine from China. This news was published through one of the accounts that has been censored by Ministery of Communication of Indonesia, and responded directly to the official page that Maheer's death was not due to being forced to inject the Covid vaccine but due to a personal illness that could not be disclosed to the public because it was related to privacy and family honor. ${ }^{49}$

\footnotetext{
${ }^{48}$ Mancino, Understanding Lists, 19.

49 https://www.kominfo.go.id/content/detail/32686/disinformasi-ustaz-maahe r-at-thuwailibi-meninggal-karena-disuntik-vaksin-sinovac/0/laporan isu hoaks
} 


\section{Web and Social Media as Expression Space}

The web and social media have been used for information and meeting spaces on a global scale. Religion, including the Muslim community, also uses it in a broad scope. Islam ${ }^{50}$ mentioned that the correct and appropriate use of social media in Muslim communities around the world has helped spread Islam significantly. Social media has the ability to enhance the nature of their open conversations, attachments and participation due to the appeal of audio visuals that are often presented to support da'wah. Da'wah groups have posted and shared da'wah by being creative in the media. Muslims can study, ask questions, teach, and network through social media sites. All Islamic information and literature are more easily accessible within the reach of the public, and it is very easy to practice Islam through an android mobile application. Android applications, appstores and others contain Islamic information including various Androids, Appstores and others containing Islamic information including various Islam-related translations such as various translations of the Qur'ān, Hadīth, fasting books, prayer schedules, doing daily life are prepared. The article also finds that there are several negative impacts that accompany the use of social media among Muslim communities. The internet is easily accessible and cheap, therefore it is also able to spread content that is harmful to Muslim morality, harmony among Muslims, and social integration of Muslims.

The Takfiri has a website as a medium of information to campaign for understanding their ideology. Meanwhile, on social media, they express their meaningful understanding when there are moments they do not agree with. For example, at this time the ruling government was a leader who was not elected by the Takfiri group, so that the public was presented with hate speech. The Takfiri group does not hesitate to accuse the government of being

\#: : :text=Beredar $\% 20$ sebuah $\% 20$ postingan $\% 20$ pada $\% 20$ media,Komunis $\% 20$ In donIndo $\% 20(\mathrm{PKI}) \% \mathrm{E} 2 \% 80 \% 9 \mathrm{D} . \&$ text=Dilansir $\% 20$ dari $\% 20$ medcom.id $\% 2 \mathrm{C}$ $\% 20$ Kepolisian, dikarenakan $\% 20$ sakit $\% 20$ yyan $\% 20$ sedang $\% 20$ diderita. Accessed on March 10, 2021.

50 Tarequl Islam, "The Impact of Society: From Islamic Perspective," International Journal of Social and Humanities Sciences (IJSHS), Vol. 3, No. 3 (November 2019), 110. 
täghüt for not carrying out laws and regulations based on the Qur'ān and Hadìth.

Indonesia, which was not built in the form of an Islamic state, had many signs sent by Takfiri groups to provide resistance to all state policies. ${ }^{51}$ One example is that when Habib Rizieq returned to Indonesia, there was a tweet on Twitter saying that "Communist benchmen are kafir liberals! Probibits the laskar from picking up the noble Dipertuan Agung Al mujabid Kabir Habib Mubammad Rizieq Shibab." Terror and accusations against the government often occur in conjunction with the cooperation of the government with various western countries such as the United States, so that they accuse the government of collaborating with infidels and even the henchmen of the infidel and their policies are also infidel and cannot be followed.

In this context, the Takfiri group gives a sign that those who do not dare to reprimand and do not defend their fellow infidels can be interpreted as defending disbelief. This seems to be taken for granted, so it can be said openly and already understand which direction the conversation is taking. For example, Habib Riziq is considered right by his followers and if not defended by him is considered wrong and considered an infidel by his followers. ${ }^{52}$

The concept of Takfiri that has developed in Indonesia is very militant, so it has eroded affection from their hearts, and it is brave and willing to sacrifice itself and its family. Likewise, riots and disorder can be carried out in order to uphold religious values which they think are true ${ }^{53}$ The examples of cases of suicide bombings several times in Indonesia, which involved themselves as the perpetrators, and the more astonishing cases of the suicide bombings in Surabaya, the perpetrators were father, mother and their child.

Other themes that have been of concern to the Takfiri group are the issue of bid'ah and other problems that are considered to be harmful of faith. A lecture from Abdul Hakim b. Amir Abdat with the theme law kanna khayran lasabaquna ilayh which criticized one of the philosophical figures, namely Ibn Sinnā, who stated that prophecy could be created. The meaning of the sentence

\footnotetext{
51 Twitter, @NewsMuslimah, posted on November 13, 2020.

52 Twitter, @MbahDinNU, posted on November 11, 2020.

53 Twitter, @Aebabahno, posted on November 10, 2020.
} 
"prophethood can be cultivated" is that a prophet-like character can be created by imitating the prophet or better known by carrying out the sunnah. However, the speaker interprets unilaterally and only partially, giving rise to a biased meaning. According to him, prophethood is only from Allah and was not created by humans, and philosophy is an intermediary for the teachings of paganism who want to integrate it with Islam. According to him, philosophy damaged Islam because many philosophical books were translated into Arabic, causing disaster for the Muslims. A fragment of Abdul Hakim's lecture which was broadcast live on the Rodja TV television channel and was reposted by an instagran account named @ tolakbidah. ${ }^{54}$

There is an Instagram post with the name@SunnahTube which states that all the innovations that exist today are bid'ah. Because innovations in Islam will only leave Islam itself, so that all innovations in Islam are bid'ah and all innovations will lead to heresy, and all heresies will lead to hellfire. It is not explained who the name of the lecturer is or when a piece of the video of the lecture was taken, it is just that it is quite clear that in the video it states that in religion there should not be innovations that the prophet never exemplified. Here it is sufficient to understand that the innovation in communication that we know as mobile phones is bid'ah because there was no prophet in the era that did not care about more benefits or disadvantages, likewise computers, the internet and even social media. But strangely, when they say that innovation in Islam is bid'ah, they still use it to spread their understanding and thoughts. It means that indirectly, they did something that they heresy and took him to hell fire. In the same account, @SunnahTube, also posted a video stating that demonstrations in Islam are not allowed. Because Islam does not recognize demonstrations and demonstrations of the actions of unbelievers and a Muslim should not follow the actions of an infidel. The lecturer also explained that the way to protest something is to discuss with the scholars and not demonstrate. ${ }^{55}$

Meanwhile, how infidels and Muslim ethics deal with infidels are also widely discussed on the website of the Takfiri groups. Some of these websites in addition to discuss not only worship

\footnotetext{
54 Instagram, @tolakbidah, posted on February 20, 2018.

55 Instagram, @SunnahTube, posted on February 18, 2017.
} 
and Muslim mu'amalah, but also discussed a lot about who and how unbelievers are. On one of the websites it was found that: ${ }^{56} 1$ ) It is haräm for a Muslim to give permission to an infidel to build a place for worship other than a mosque in a Muslim country; 2) Avoiding shirk and kufr along with those who practice it and always keep a distance from these people; 3) Not electing a leader from the infidels; 4) Do not give help to unbelievers, even praise their achievements and do not give help to unbelievers who ask for help to be able to face Muslims; 5) Do not ask for help or receive assistance in any form from unbelievers and do not make them trustworthy friends or friends; 6) It is prohibited to joke with an infidel which can harm religion; 7) Not following the law or relying on the law that has been made by infidels; 8) Do not ask Allah for forgiveness of the infidels' sins that they have committed; 9) Do not imitate or look and style like an infidel because that is a big sin; 10) Loss of heirs between Muslims and infidels.

The ideological of Takfiri uses al-walä' wa al-barä' as a doctrine. At least there are several websites that have been campaigned to join this doctrine. ${ }^{57}$ One of the scholars who was used as a reference was Shaykh 'Abd al-'Aziz b. Bāz. He stated that al-walä' wa al-bara' 's love and loyalty to believers and hate and hostile to infidels, apart from the doctrine of infidels. According to the opinion of the scholar Shaykh Șālih al-Fawzan, between the Islamic creed of a Muslim, it is obligatory to wal $\vec{a}$ to the Muslims and be hostile to the enemies of Islam, love and wala' to people who are monotheistic and hate the perpetrators of shirk. ${ }^{58}$

This is the postmodern era where cultural, religious, modern and traditional values overlap each other. In this context, Takfiri creates a mark on the infidels, at the same time they use social media which incidentally was made by infidels. From the ideological understanding, that is easily disseminated through various website pages, there are evident that social media is a

\footnotetext{
56 Available at https://almanhaj.or.id/6192-hukum-bermuamalah-denganorang-kafir-2.html; https://almanhaj.or.id/13832-wajib-waspada-kepada-orangkafir-serta-wajib-bara-kepada-orang-kafir.html

${ }^{57}$ Available at https://asysyariah.com/keharusan-membenci-dan-berlepas-diridari-orang-kafir/

58 Available at https://asysyariah.com/keharusan-membenci-dan-berlepas-diridari-orang-kafir/
} 
means for the spread of Takfiri understanding that is easy, cheap and free. Anyone can access it freely without having to worry about being suspected of being one of the members of the Takfirism. Many of the signs expressed by this group were captured without criticism and reflection, even though the antihumanitarian message had lost lives and feelings of fear.

Eco insisted that in the world of new media, new forms of criticism should be explained today. Eco is concerned that mediated and digital communication technology endangers critical thinking and reflection, while on the other hand this medium facilitates the goal of endless progress. Eco urged the importance of continuously practicing and teaching critical skills amid the continuing evolution of mass media. He wrote, "My idea is: since you do not have the power to change the media, try to change every day the way people receive their messages." Eco's original application from 1967 remains relevant for human communication in the second decade of the twenty-first century, securing Eco's relevance to critical and cultural communication questions and his ongoing work. Hay's interview with Eco emphasizes the continuing implications of Eco's early and late work that shaped the fuel research questions published in Communication and Critical of Cultural Studies. ${ }^{59}$

Relevant to the message put forward by Eco above, critical power of signs with religious symbols should still be done. An interesting analysis is presented in the research of Ammar et al, ${ }^{60}$ on the proliferation of Salafi content and exports around the world. Religion plays an important role in people's lives in the Middle East, ideologically driven groups, such as Fateh al-Sham and Islamic State. They have to compete in the consumer market with a myriad of other Islamic groups. Supporters of the alSalafizah al-jibäizyah movement seem to realize the importance of "religious branding." As a group with a clear political agenda, Salafis recognize the need for a motto to ensure their base. By systematically and carefully linking activities to Qur'ānic verses or the Prophet's Hadīths, Salaf-Jihadists have succeeded in characterizing criticism leveled against their agenda as an attack on Islam and Muslims, thereby mobilizing large crowds to the slogan of the self-

\footnotetext{
${ }^{59}$ Mancino, Understanding Lists, 20.

${ }^{60}$ Jamil Ammar and Songhua Xu, When Jihadi Ideology Meets Social Media (Springer Nature: Switzerland, 2018), 27-30.
} 
proclaimed Islamic Caliphate. Radical Jihadists have long justified their politically driven goal by using carefully selected metaphorical verses from the Koran or the Prophet's Hadiths.

In a pluralistic context in Indonesia, both in terms of religious understanding within one religion, as well as the diversity of religions, the ideology of Takfiri is very disturbing and disturbs social integration, tolerance and harmony. Islam in Indonesia puts forward the wasatiyah. Wasatiyah Islam is one of the solutions that come to combat the ideology of Takfiri. Wasatizah Islam itself can be interpreted as an understanding of moderate Islam which opposes violence, fanaticism, extremism, terrorism and defends those who are wronged. This opposing criterion which the writer calls an ideological tool against the Takfiri ideology which has been widely diverted. ${ }^{61}$

The religious perspective also affects how a person can understand the religion that has been bestowed on mankind. According to religious phenomenologists, there are two ways of seeing and understanding religion, namely the nomos or laworiented religion and the love-oriented religion. The doctrine of Takfirism can be easily traced by referring to the perspective of a harsh religion and the laws it implements, therefore an exclusive attitude is formed and tends to ignore other people who are not included in the group and can be accompanied by actions to deprive that person of the world because they believe there is one obligation to punish people who have violated the law of his Lord. ${ }^{62}$

\section{Conclusion}

Takfiri ideology, which uses online media as a medium of communication to spread his radical ideology, has generated a large following. The article with Eco's semiotic perspective that questions the communicational aspects and expressions of Takfiri in online media produces conclusions. First, the reach of online media in today's era makes a variety of information, including false information, propaganda and others easier to do because it is wide,

\footnotetext{
${ }^{61}$ Agus Zaenul Fitri, "Pendidikan Islam Wasathiyah: Melawan Arus Pemikiran Takfiri di Nusantara," KURIOSITAS: Media Komunikasi Sosial dan Keagamaan, Vol. 8, No. 1 (June 2015), 45-54.

${ }^{62}$ Bagir, Islam Tuban Islam Manusia, 49-53.
} 
free, and cheap. Eco, who died in 2016, saw how powerful the internet is as a tool for information media. Eco calls the website the "Mother of All Lists" algorithmic processing of big data on the internet media has threatened cultural development, by limiting human involvement in significance and communication. The rise of Takfiri content in online media, which has led to radical attitudes in some circles of society, shows that the sign messages produced by these groups have been captured and without any critical thinking process. This raises the question of how online media has produced signs. In this context, Eco emphasized the importance of semiotics and emphasized its contribution to interpretative semiotics, so that the signs ordered by the communicator are interpreted through a critical thinking process. Second, Takfirism spreads its ideology through various website pages and social media. On their website many express the attitude of al-walä' wa al-bara $\overline{\text {. }}$. They refer to one of the scholars who stated that al-walä' wa al-barā' is love and loyalty to the believers and hate and hostile to infidels, the Islamic creed of a Muslim is obliged to wal $\vec{a}$ to the Muslims and is hostile to the enemies of Islam, love and wal $\vec{a}$ to people who believe in monotheism and hate the perpetrators of shirk. On social media, they express their understanding of their infidels when there are moments that they do not agree with. Actual events in Indonesian society, even in the world, are utilized through various posts on social media, to show the "truth" of their ideology.

\section{Bibliography}

Ammar, Jamil and Songhua Xu. When Jihadi Ideology Meets Social Media. Springer Nature: Switzerland, 2018.

Azhar. "Analisis Komparatif Konsep TakfirAntara Salaf Dan Khalaf," Al-Lubb, Vol. 2, No. 1, 2017.

Badar, Mohamed. "Masaki Nagata andTiphanieTueni dengan judul The Radical Application of the Islamist Concept of Takfir," Arab Law Quarterly, Vol. 31, 2017.

Bagir, Haidar. Islam Tuban Islam Manusia: Agama dan Spiritualitas di Zaman Kacau. Bandung: Mizan, 2019.

Celso, Anthony N. "Jihadist Organizational Failure and Regeneration: The Transcendental Role of Takfiri Violence." 
A paper prepared for presentation at The Political Studies Association Meeting, Manchester, England, April 14-16, 2014.

Djelantik, Sukawarsini et al. Komunikasi Melalui Media Sosial oleh The Islamic State (IS) di Indonesia. Bandung: LP2M Universitas Parahyangan, 2015.

Eco, Umberto. Teori Semiotika: Signifikasi Komunikasi, Teori Kode, Serta Teori Produksi-Tanda, translated by Inyiak Ridwan Muzir. Kreasi Wacana: Bantul, 2016.

Fitri, Agus Zaenul. "Pendidikan Islam Wasathiyah: Melawan Arus Pemikiran Takfiri di Nusantara," KURIOSITAS: Media Komunikasi Sosial dan Keagamaan, Vol. 8, No. 1, June 2015.

Ghazzi (al), Omar. "Modernity as a False Deity: Takfiri Anachronism in the Islamic State Group's Media Strategy," Javnost: The Public, 2018.

Ghifari, Imam Fauzi. "Radikalisme Di Internet," Religious: Jurnal Agama dan Lintas Budaya, Vol. 1, No. 2, 2017.

Halim, Amanullah. Buku Putih Kaum Jihadis: Menangkal Ekstremisme Agama dan Fenomena Pengafiran. Tangerang: Lentera Hati, 2015.

Hassan, Muhammad Haniff. "The DangerofTakfir (Excommunication): Exposing IS' Takfiri Ideology," Counter Terrorist Trendsand Analyses, Vol. 9, No. 4 (April 2017).

Helland, Christopher. "Online Religion as Lived Religion: Methodological Issue in the Study of Religion Participation on the Internet," Heidelberg Journal of Religions on the Internet, Vol. 1, No. 1, 2005.

Hidayatullah, Moch Syarif. "The Sectarian Ideologyofthe Islamic Online Media in Indonesia," INS ANIY AT: Journal of Islam and Humanities, Vol. 1, No. 2, May 2017.

Hosen, Nadirsyah. Saring sebelum Sharing. Yogyakarta: Bentang, 2019.

https://almanhaj.or.id/13832-wajib-waspada-kepada-orang-kafirserta-wajib-bara-kepada-orang-kafir.html

https:/ /almanhaj.or.id/6192-hukum-bermuamalah-dengan-orangkafir-2.html

https://asysyariah.com/keharusan-membenci-dan-berlepas-diridari-orang-kafir/

https://islam.nu.or.id/post/read/98243/mengafirkan-sesamamuslim-takfiri-dulu-dan-sekarang accessed on March 5, 2021. 
https://www.kominfo.go.id/content/detail/32686/disinformasiustaz-maaher-at-thuwailibi-meninggal-karena-disuntik-vaksinsinovac/0/laporan_isu_hoaks\#: :text=Beredar $\% 20$ sebuah $\%$ 20postingan $\% 20$ pada $\% 20$ media,Komunis $\% 20$ IndonIndo $\% 20$ (PKI) $\%$ E2\%80\%9D.\&text $=$ Dilansir\%20dari $\% 20$ medcom.id $\% 2 \mathrm{C} \% 20$ Kepolisian, dikarenakan $\% 20$ sakit $\% 20$ yyan $\% 20$ sedang \%20diderita. Accessed on March 10, 2021.

https://youtu.be/hlPX5RXtXcY, accessed on March 4, 2021. Idahram, Shaykh. Ulama Sejagad Menggugat Salafi Wahabi. Yogyakarta: Pustaka Pesantren, 2011.

Indah, Nuria. "Pengaruh Media Sosial Terhadap Penyebaran Paham Terorisme Islamic State Of Iraq and Syiria (ISIS) di Indonesia”. Undergraduate Thesis--Universitas Pasundan, 2019.

Instagram, @SunnahTube, posted on February 18, 2017.

Instagram, @tolakbidah, posted on February 20, 2018.

Islam, Tarequl. "The Impact of Society: From Islamic Perspective," International Journal of Social and Humanities Sciences (IJSHS), Vol. 3, No. 3, November 2019.

Juli, Sabiruddin. "Saring sebelum Sharing, Mengenal Berita Hoax, Radikalisme di Media Sosial," Al Munir: Jurnal Komunikasi dan Penyiaran Islam, Vol. 10, No. 1, 2019.

Kepel, Gilles. The War for Muslim Minds: Islam and theWest, translated by Pascale Ghazaleh. London: Belknap-Harvard University Press, 2004.

Mancino, Susan. Understanding Lists: Umberto Eco's Rhetoric of Communication and Signifcation. Ph.D. Dissertation--Duguesne University, 2018.

Mandhūr, Ibn. Lisān al-'Arab. Kairo: Dār Ma'ārif, 1119.

Manning, Peter K. and Betsy Cullum Swan, "Analisis Naratif, Analisis Konten dan Analisis Semiotik," in Norman K. Denzin, Handbook of Qualitative Research. Yogyakarta: Pustaka Pelajar, 2009.

Newell, Steven W. Global Takfiri Radicalization: A Center OfGravityDeconstruction. Newport: Naval War College, 2010.

Rahman, Abdul and Tommy F. Awuy. "Semiotika Filosofis: Perspektif Umberto Eco." Undergraduate Thesis--Universitas Indonesia, 2013. 
Rahmatika, Arina. "Citra Wahabi Di Media Massa," Mediakita, Vol. 2, No. 2, July 2018.

Rao, Ammara Rabbani. Takfiri a Messianic Ideology: Counter Measures for Radical Insurgents in Waziristan," Tigah: A Journal of Peace and Development, Vol. 4, 2014.

Sarıül, Fatma Altınbaş. "The Impact of Print Media on Popular Culture: Umberto Eco's Number Zero," Istanbul Kemerburgaz. University Journal of Social Sciences, Vol. 1, No. 1, 2016.

Solik, Martin. "Semiotic Approach to Analysis of Adverting," Journal of Science and Theology, Vol. 10, No. 1, October 2014.

Sulfikar, Achmad. "Swa-radikalisasi Melalui Media Online di Indonesia", Jurnalisa, Vol 4, No. 1, May 2018.

Sutkute, Rita. "Media, Stereotypes and Muslim Representation: World After Jyllands-Posten Muhammad Cartoons Controversy," EUREKA: SocialHumanities, No. 6, 2019.

Twitter,@Aebabahno,posted on November 10, 2020.

Twitter,@Aldoaria, posted on November 13, 2020.

Twitter,@islamidotco,posted on November 13, 2020.

Twitter,@MbahDinNU, posted on November 11, 2020.

Twitter,@NewsMuslimah, posted on November 13, 2020.

Wahid, Din. "Pentas Jihad Gerakan Salafi Radikal Indonesia," Studia Islamika, Vol. 14, No. 2, 2007.

Widodo, M. Hafidh. "Ideologi Takfiri Muhammad Al-Maqdisi: Memahami Hubungan Beragama dan Bernegara Perspektif Maqāshid asy-Syarī'ah," Living Islam: Journal of Islamic Discourses, Vol. 1, No. 2, November, 2018.

Zulfadli. "Pendidikan Politik dalam Menangkal Pemahaman Radikalisme Agama bagi Pemuda Muhammadiyah di Kecamatan Pariaman Utara, Kota Pariaman," Warta Pengabdian Andalas, Vol. 26, No. 1, 2019. 